\title{
Cloxacillin and Sodium Fusidate in Management of Shunt Infections
}

\author{
R. RAO, \\ A. B. D. WEBSTER, \\ D. R. SUNDERLAND, \\ W. F. SMITH, \\ S. AMPALAM, \\ H. A. LEE
}

British Medical fournal, 1972, 3, 618-619

\section{Summary}

The effectiveness of two oral antibiotics, cloxacillin and sodium fusidate, has been evaluated in the treatment of shunt infections among 37 patients allocated at random to two treatment groups. Both proved to be safe bactericidal agents giving adequate serum M.I.C. when taken by mouth. Treatment should always be started on the basis of the clinical presentation without waiting for the bacteriologist's report. The commonest infecting organism is Staphylococcus aureus. Nine shunts were lost in this study, eight through Staphylococcus aureus infection. The nasal carrier state is of considerable importance in perpetuating these shunt infections.

\section{Introduction}

Infection of arteriovenous shunt sites in patients on regular maintenance haemodialysis continues to be a major problem. When such infections occur the organisms involved are often staphylococci (Mantin et al., 1967). Effective and early treatment is vital if an infected shunt is to be saved and septicaemia averted. The choice of antibiotic may be difficult, particularly as many of the staphylococci will have a wide range of antibiotic resistance. Ideally the antibiotic selected should be bactericidal with marked antistaphylococcal activity and should be effective when given by mouth, thus avoiding the difficulties of intravenous administration and the haemorrhagic complications of intramuscular injections in anticoagulated patients. The dose regimen should not need adjustment according to the degree of renal failure and the drug should not be removed from the blood during haemodialysis (Eykin et al., 1970).

We have compared the bacteriological and clinical effects of cloxacillin and sodium fusidate in patients on regular haemodialysis treatment who developed shunt infections, most of which were due to staphylococci.

\section{Method}

Trial cards were prepared in batches of six. Each batch contained a random allocation of sodium fusidate and cloxacillin therapy, such that with each batch three patients would be treated with each antibiotic. The initial grouping of patients was blind to the doctors managing the trial, although they were aware of the therapy to which individual patients had subsequently been allocated. All patients had SilasticTeflon leg shunts. At each dialysis the skin area was cleaned

Wessex Regional Renal Unit, St. Mary's Hospital, Portsmouth R. RAO, M.R.C.P., Medical Registrar

A. D. B. WEBSTER, M.R.C.P., Medical Registrar

D. R. SUNDERLAND, S.R.N., Sister

W. F. SMITH, S.R.N., Charge Nurse

H. A. LEE, M.R.C.P., Consultant Physician and Senior Lecturer in Renal
Medicine

Public Health Laboratories, Portsmouth

S. AMPALAM, M.B., DIP. BACT., Registrar with normal saline and then covered with a dry gauze dressing. The shunts were left undisturbed between dialyses.

Patients were admitted to the trial on the basis of suspected clinical infection of their shunts-manifested by pain, inflammation, and discharge.

Without awaiting swab results patients were given loading doses of $500 \mathrm{mg}$ of cloxacillin with $500 \mathrm{mg}$ of ampicillin or $500 \mathrm{mg}$ of sodium fusidate with a similar dose of ampicillin according to instructions on the trial card drawn for the patient. The two drugs were then continued at a dosage of $250 \mathrm{mg}$ four times a day. If a laboratory report was received confirming the presence of staphylococci, then ampicillin was discontinued and cloxacillin or sodium fusidate therapy continued for a total of 10 days.

The swab report was invariably received within 24 hours. Ampicillin was included in the regimen as a safeguard against infections not attributable to staphylococci. Since ampicillin was common to both therapeutic regimens the cases in the two groups were strictly comparable. The limb of the shunt infected, duration if shunt life, and any previous infective episodes were noted.

Additional swabs were taken from the nose, umbilicus, axillae, perineum, and hair to detect the presence of a carrier state. All swabs were examined for sensitivity to cloxacillin, sodium fusidate, ampicillin, and a number of other antibiotics.

The clinical features monitored were pain, inflammation, discharge, and viability of the shunt.

Bacteriological monitoring of the shunts was carried out on days $0,5,10,20$, and 30 . Patients whose swabs were still positive on the 10th day were regarded as therapeutic failures. In all cases trained unit nursing staff were responsible for taking swabs as outlined and for recording data. All patients were receiving warfarin sodium as an anticoagulant.

Bacteriological Studies.-Standard bacteriological plating was carried out using media of blood agar (aerobically and anaerobically), MacConkey, and electrolyte-deficient agar containing mannitol. Routine phage typing was carried out as described by Williams and Rippon (1952). Methicillin and cloxacillin resistance was tested after overnight incubation of plates at $30^{\circ} \mathrm{C}$, thus allowing the effects of temperature (Parker and Hewitt, 1970). Bacteria were cross-checked with known strains of staphylococci provided by the Public Health Laboratory, Colindale, and at all times control plates were put up with those under investigation. Antibioic blood levels were estimated at 10-12 hours after the last dose of the antibiotic in 14 cases selected at random, the patients having been dialysed intercurrently.

\section{Results}

Thirty-seven patients were admitted to the trial. In Table I the bacteriological and clinical progress of the patients in the two groups is compared at 0 and 10 days.

An analysis of other positive culture sites in those patients with initially positive shunt swabs is given in Table II.

All the organisms from positive shunt swabs were phage typed, and this information will form the basis of another paper. An interesting pattern emerged relating to phage type $29 / 77$, which is usually associated with methicillin resistance but which was not the case in this unit. 
TABLB I-Bacteriological and Clinical Progress in the 37 Cases

\begin{tabular}{|c|c|c|c|c|c|c|c|c|c|c|}
\hline & \multicolumn{5}{|c|}{$\begin{array}{c}\text { Cloxacillin Group } \\
\text { (16 Patients; } 6 \text { (38\%) } \\
\text { Shunts Lost) }\end{array}$} & \multicolumn{5}{|c|}{$\begin{array}{l}\text { Sodium Fusidate Group } \\
\text { (21 Patients; } 3(14 \%) \\
\text { Shunts Lost) }\end{array}$} \\
\hline & \multicolumn{3}{|c|}{ Bacteriology } & \multicolumn{2}{|c|}{$\begin{array}{c}\text { Clinical } \\
\text { Signs }\end{array}$} & \multicolumn{3}{|c|}{ Bacteriology } & \multicolumn{2}{|c|}{ Clinical- } \\
\hline & हूँ & 苛 & 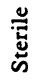 & $\stackrel{0}{y}$ & zo & $\frac{\dot{0}}{\dot{\Xi}}$ & 苫 & 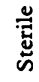 & $\stackrel{8}{\nu}$ & $\stackrel{\circ}{z}$ \\
\hline $\begin{array}{l}\text { Infected day } 0 \ldots \\
\text { Infected day } 10 . \\
\text { Non-infected day } 0 \\
\text { Non-infected day } 10\end{array}$ & $\begin{array}{l}9 \\
3\end{array}$ & $\begin{array}{l}1 \\
0\end{array}$ & $\begin{array}{l}0 \\
7 \\
6 \\
6\end{array}$ & $\begin{array}{r}10 \\
4 \\
6 \\
1\end{array}$ & $\begin{array}{l}0 \\
4 \\
0 \\
5\end{array}$ & $\begin{array}{l}6 \\
2 \\
0 \\
0\end{array}$ & $\begin{array}{l}2 \\
0 \\
0 \\
1\end{array}$ & $\begin{array}{r}0 \\
6 \\
13 \\
12\end{array}$ & $\begin{array}{r}8 \\
6 \\
13 \\
5\end{array}$ & $\begin{array}{l}0 \\
1 \\
0 \\
7\end{array}$ \\
\hline
\end{tabular}

The number of patients in the clinical signs column does not in all cases correspond to the total number of patients investigated. These discrepancies were due to inadethe total number of patio documentation.

TABLE II-Positive Shunt Swabs and Swab Analysis

\begin{tabular}{c|c|c|c|c}
\hline \multirow{2}{*}{ No. of Patients } & \multicolumn{2}{|c|}{ Shunt } & $\begin{array}{c}\text { Nose } \\
\text { (Staph.) }\end{array}$ & $\begin{array}{c}\text { Other Sites } \\
\text { (Staph.) }\end{array}$ \\
\cline { 2 - 4 } & Staph. & E. coli & 11 & 4 \\
\hline 15 & 3 & 11 &
\end{tabular}

Three other patients subsequently developed positive shunt swabs during the trial period. In none of these were any of the other site swabs positive-that is, they were not carriers.

TABLE III-Clinical Sequelae of Shunt Trial

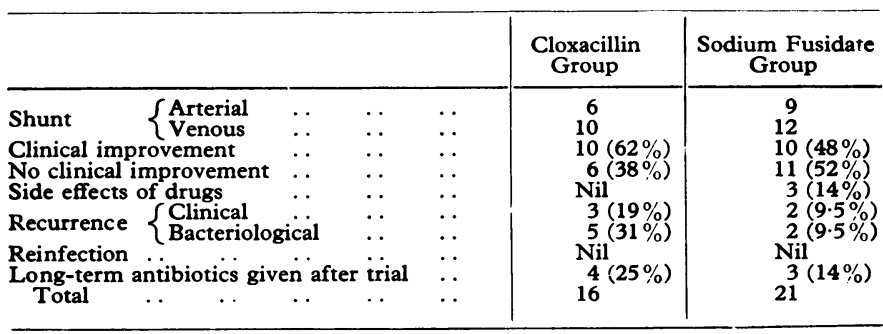

In Table III the overall bacteriological and clinical sequelae of the shunt trial are shown. There was no statistical difference in clinical improvement between the two treatment groups $\left(\chi^{2}=0.81\right)$ or in loss of shunts $\left(\chi^{2}=2.67\right.$; see Table I). Previous infective episodes had occurred in nine patients receiving cloxacillin and in 12 receiving sodium fusidate, there being no statistical difference between the groups. The commonest previous infecting organism was Staphylococcus aureus. Side effects of therapy were manifested by gastrointestinal symptoms (nausea and epigastric pain) in two patients and by pruritus in one. Precise instructions about taking sodium fusidate with meals might have prevented some of these symptoms.

Bacteriological recurrence was defined for the purposes of this trial as the recurrence of positive shunt swabs at day $\mathbf{3 0}$ occurring after a previous negative swab at day 10. Bacteriological reinfection was defined as a positive shunt swab with a different organism occurring at day 30 after previous negative swabs at day 10 . There was no statistical significance between the recurrence and reinfection rates in the two groups.

Long-term antibiotic therapy was indicated in four patients $(25 \%)$ in the cloxacillin group and in three $(14 \%)$ in the sodium fusidate group. These patients. still had evidence of continuing clinical or bacteriological infection or both after completion of the trial or following 10 days of antibiotic therapy. In the patients whose antibiotic levels were measured the mean sodium fusidate level at 10-12 hours after the last dose was $3.6 \mu \mathrm{g} / \mathrm{ml}$ and the mean cloxacillin level $2.2 \mu \mathrm{g} / \mathrm{ml}$. Both these levels are acceptable in terms of M.I.C. for Sa aph. aureus in serum (Garrod and O'Grady, 1968).

\section{Discussion}

In spite of positive clinical signs $38 \%$ and $64 \%$ of the patients in the cloxacillin and sodium fusidate groups respectively were found to have sterile shunt swabs. Variations in swab results from the same shunt were also noted, and this may reflect the inadequacies of the technique of swab taking.

In both groups cases with both clinical and bacteriological evidence of shunt infection resolved more slowly and the prognosis was more serious. Out of 15 patients who initially had a Staph. aureus infection eight $(55 \%)$ lost their shunts; a finding which stresses the seriousness of such infections yet not their total hopelessness (Martin et al., 1967). There was no predilection for staphylococcal infection to involve a particular limb of the shunt.

Adequate serum cloxacillin and sodium fusidate levels were obtained with our regimen and confirm the findings of previous workers (Linton et al., 1968; Hobby et al., 1970). The most common carrier site in patients with staphylococcal shunt sepsis is the nose (Williams, 1963). Our policy is to swab the nasal passage of our prospective shunt patients, and should a staphylococcus be found we prescribe a 10-day course of Naseptin (chlorhexidine hydrochloride $0.1 \%$, neomycin sulphate $0.5 \%$ ) twice a day before the shunt is inserted. Finally, in patients who have repeated Staph. aureus shunt infections just as much attention should be paid to elimination of the nasal carrier state as to treating individual shunt infections.

Our results show that clinical signs must always take precedence over the bacteriological evidence of a shunt infection. Both sodium fusidate and cloxacillin are good bactericidal agents, and in this small series of patients no statistically significant differences emerged between the two antibiotics. We believe that shunts which appear clinically infected should be initially treated without awaiting bacteriological results. A combination of either cloxacillin or sodium fusidate with ampicillin by mouth will adequately cover the vast majority of shunt infections. Effective, early, and appropriate antibiotic therapy will salvage many infected shunts and improve the present situation, which led to the statement "the occurrence of a shunt infection of ten resulted in the need to resite the shunt" (Ralston et al., 1971). Our shunt salvage rate seems acceptable compared with previous reports (Farooki et al., 1970) and diminishes the need for using more potentially troublesome antibiotics.

Drug resistance to both sodium fusidate and cloxacillin did not occur in any of our trial patients or others subsequently studied. Should long-term antibiotic therapy be needed sodium fusidate seems appropriate, since bacterial resistance to it is very rare (Taylor and Bloor, 1962).

We wish to thank Leo Laboratories for arranging the estimation of serum levels of sodium fusidate and cloxacillin and for preparing the trial cards. We are also grateful to the haemodialysis unit nursing staff and the bacteriological technical staff for their help.

\section{References}

Eykyn, S., Phillips, I., and Evans, J. (1970). British Medical fournal, 3, 80. Farooki, M. S., Gergeley, N. F., McA Aninch, L. N., Coates, R. K., and Kimber, R. W. (1970). Canadian Medical Association fournal, 103, 1371 .

Garrod, L. P., and O'Grady, F. (1968). Antibiotic and Chemotherapy, 2nd Rod, L. P., and O'Grady, F.

Hobby, J. A. E., Beeley, L., and Whitby, J. I. (1970), fournal of Clinical Pathology, 23, 484.

Linton, A. L., Lawson, D. H., MacVarish, I., and Eakins, J. S. (1968). Proceedings of the European Dialysis Transplant Association, 5, 153 .

Martin, A. M., Clunie, G. J. A., Tonkin, R. W., and Robson, J. S. (1967) Proceedings of the European Dialysis Transplant Association, 4, 373.

Parker, M. T., and Hewitt, J. H. (1970). Lancet, 1, 800.

Ralston, A. J., Harlow, G. R., Jones, D. M., and Davis, P. (1971). British Medical fournal, 3,408 .

Taylor, G., and Bloor, K. (1962). Lancet, 1, 935.

Williams, R. E. O. (1963). Bacteriological Reviews, 27, 56.

Williams, R. E. O., and Rippon, J. E. (1952). Fournal of Hygiene, 50, 320. 